\title{
Fair Arbitration Decision for Parties to the Dispute Based on The Act Arbitration
}

\author{
Jeanne Darc Noviayanti Manik \\ Faculty of Law \\ Universitas Bangka Belitung \\ Pangkalpinang, Indonesia \\ novi_palembang@yahoo.com \\ Wirazilmustaan \\ Faculty of Law) \\ Universitas Bangka Belitung) \\ Pangkalpinang, Indonesia \\ wira.aan@gmail.com
}

\begin{abstract}
The law governing the dispute material in arbitration and Alterntive Dispute Resolution is the law selected in the relevant commercial agreement that poses a dispute between the parties. In the event by the parties to the agreement not set forth on governing law, the parties freely elect the applicable law under a mutual agreement. The method used is normative legal research. The purpose of writing is to analyze the implementation of arbitration decisions both nationally and internationally. Settlement of disputes or disagreements through an alternative dispute resolution is settled in a direct meeting by the parties within a period of 14 (fourteen) days and the result is set forth in a written agreement. In the event that a dispute or disagreement cannot be resolved, then the parties ' written agreements, disputes or disagreements are resolved through the assistance of one or more expert advisors or through a mediator. The proof tools used in the examination are witnesses, expert witnesses, and documents relating to the dispute. Settlement of disputes through arbitration may be conducted using national or international arbitral institutions based on agreement of the parties. The arbitrator or the arbitral tribunal shall take the verdict under the provisions of the law, or based on fairness and compliance. The arbitral decision is final and has a fixed legal force and binding of the parties
\end{abstract}

Keywords — component, formatting, style, styling, insert

\section{INTRODUCTION}

Arbitration is a means of resolving a civil dispute outside a public court based on an arbitration agreement made in writing by the disputing parties. The parties are the subject of law, both under civil and public law. At first the arbitration was established by traders as an alternative dispute resolution than they had to litigate in a court that often took a long time and his judges ' skills were considered very generalist. They are eager to make a "private court", where they can make their own legal proceedings or in arbitration terms called the 'Rule' as well as the arbitrations they can raise themselves with their specified lectures. Settlement of a dispute may only be exercised if there is an agreement or agreement between the parties to resolve their dispute through arbitration. This agreement may be made before a dispute arises or is referred to as Pactum de Compromitendo or after a dispute arises called the act of compromise.

The arbitral decision is final and binding means that the ruling cannot be requested by legal remedies such as appeals and casings and the ruling is binding on the parties to be voluntarily adhered to in good faith. Because before the verdict was made they have also agreed to finish it through the arbitration line with all its consequences. ${ }^{1}$

\section{THEORY AND HYPOTHESIS}

The arbitrator shall be one or more elected by the parties to the dispute or appointed by the District Court or by an arbitral institution, to provide a ruling on a particular dispute submitted by arbitration.

The arbitral tribunal is the body elected by the parties to dispute to decision a particular dispute; The agency may also provide binding opinions on a particular legal relationship in the event of a dispute.

The decision of an international arbitration shall be the ruling imposed by an arbitral institution or individual arbitrator outside the jurisdiction of the Republic of Indonesia, or the ruling of an arbitral institution or individual arbitrator who, according to the provisions of the Republic of Indonesia regarded as an international arbitration decision. 
Alternative dispute resolution is a dispute resolution institution or disagreement through a procedure agreed upon by the parties, i.e. a settlement outside the court by means of consultation, negotiation, mediation, conciliation, or expert judgment

Disputes or different civil opinions may be resolved by the parties through an alternative dispute resolution that is based on good faith by the exclusion of a litigation settlement in the District Court.

Settlement of disputes or disagreements through an alternative dispute resolution is settled in a direct meeting by the Parties within a period of 14 (fourteen) days and the result is set forth in a written agreement. In the event that a dispute or disagreement cannot be resolved, then the parties ' written agreements, disputes or disagreements are resolved through the assistance of one or more expert advisors or through a mediator. If the parties in the period of 14 (fourteen) days with the help of one or more expert advisors or through a mediator did not succeed to reach the said agreement, or the mediator did not manage to bring the two parties, then the parties may contact an arbitral institution or an alternative dispute resolution institution to appoint a mediator. After the appointment of a mediator by an arbitral institution or an alternative institution of dispute resolution, within a period of 7 (seven) days the mediation business must already be initiated

\section{DATA SET AND METHODS}

The research conducted in this writing is legal research, which is a process of discovering the rule of law, principles of law and doctrine of the law to answer the legal issues encountered. $^{2}$ In discussing legal issues in this paper is used approach to legislation and conceptual approach. The conceptual approach is to elaborate on a number of legal concepts, legal theory, principles of law and doctrine in order to generate problems both well and reasonable. The statutory approach is used in relation to applicable laws and regulations. The legal material used primarily is the primary legal ingredient, which is a formal legal material in the form of legislation related to the subject matter of the Arbitration Act as well as secondary legal material that provides explanation of the primary legal material in the form of research results such as books and legal scientific journals.

\section{FINDINGS}

\section{A. National Arbitration}

The Tribunal shall first seek to prevent the parties from seeking a peaceful settlement, either for the efforts of the parties themselves or with the assistance of a mediator or other independent third party or with the assistance of the tribunal if agreed by the parties. In the case of a peaceful settlement, the Tribunal shall prepare a memorandum of such peace agreement in writing that has the force of law and binds both parties and may be executed in the same manner as a decision from the tribunal. Failure to settle peacefully in the case of unsuccessful peaceful settlement, the Tribunal shall continue the arbitration procedure in accordance with the provisions of the regulation.
The only excess of arbitration against the court was its confidential nature because its decision was not published. However, the dispute resolution by arbitration is still more desirable than litigation, especially for business contracts that are international. With the development of the business and the development of traffic in the field of trade both national and international as well as the development of the law in general, the regulation contained in Reglemen Civil Proceedings (Reglement op de Rechtvordering) Used as an arbitration guideline is no longer appropriate so it needs to be adjusted because the international trade arrangement is already a necessity of conditio sine qua non while it is not regulated in the Reglemen Civil Proceedings ( Reglement op de Rechtvordering). Departing from this condition, a fundamental change to the Reglemen of Civil Proceedings (Reglement op de Rechtvordering) both philosophical and substantive was time to be implemented.

The legal scope of trade is activities, among others, in the field of:
a. Business;
b. Banking;
c. Finance;
d. Investing;
e. Industry;
f. Intellectual property rights.

The arbitration set out in the Arbitration Act is a means of resolving a dispute outside the General Court based on the written agreement of the disputing party but not all disputes may be resolved by arbitration, It is only a dispute about the rights under which the law is fully controlled by the parties who dispute on the basis of their said agreement. It is intended to keep lest the resolution of disputes through arbitration become protracted. Unlike the state court process in which the its verdict of the parties can still appealed and appeal, then in the process of dispute resolution through arbitration is not open the legal effort appeal or reconsideration.

Efforts to settle disputes or disagreements through the mediator, by holding firmly confidentiality, in the period of 30 (thirty) days must be reached an agreement in writing signed by all parties concerned. The agreement of dispute resolution or disagreements in writing is final and binding on the parties to be executed in good faith and must be registered in the District Court within 30 (thirty) days since the signing.

In the Arbitration Act, it is governed by several fundamental points, such as:

a. The parties may approve a dispute occurring or that will occur between them to be resolved by arbitration (Article 7)

b. Disputes that may be resolved by arbitration are only disputes in the field of trade and of rights under which the law and regulations are fully controlled by the disputing parties. Disputes that cannot be resolved by arbitration are disputes that according to statutory regulations can not be held peace. (Article 5)

c. All examination of disputes by arbitrators or arbitral tribunal is conducted in a closed. (Article 27)

d. Settlement of disputes through arbitration may be conducted using national or international arbitration institutions based on the agreement of the parties. 
Settlement of disputes through arbitral institutions is conducted under the rules and events of the selected institution, unless otherwise stipulated by the parties.

e. The arbitrator or the arbitral tribunal may order that any document or evidence be accompanied by a translation into the language stipulated by the arbitrator or the arbitral tribunal (Article 35)

f. Examination of disputes in arbitration shall be in writing. Oral examination may be performed upon approval of the parties or deemed necessary by the arbitrator or the arbitral tribunal. (Article 36)

g. Place of arbitration determined by the arbitrator or the arbitral tribunal, unless otherwise specified by the parties (Article 37)

In the event that the burden of proof then each party is obliged to explain the position of each, to propose evidence that strengthens its position and to prove the facts made as the basis of demands or answers. The Tribunal may, if deemed necessary, ask the parties to provide explanations or submit documents deemed necessary and/or to convey the summary of the entire document and other evidence that has been and/or will be filed by the parties to support the facts in the claim application letter or the answer letter, within the period stipulated by the Tribunal. The weight of the tribunal's proof should determine whether the evidence is acceptable, relevant and concerned about the matter and has the power of evidence.

If the Tribunal considers it necessary and/or at the request of each party, the expert witnesses or witnesses relating to the facts may be called. The witnesses by the Tribunal may be asked to bear their testimonies in written form. The Tribunal may determine, in its sole discretion or at the request of each party, whether it is necessary to hear the oral testimony of the witnesses. The party requesting the calling of a witness or expert witness shall pay upfront all necessary fees in relation to the presence of the witness. For that purpose the Tribunal may request that it be first deposited into a deposit to the Indonesian National Arbitration Board. Before bearing their testimonies, the witnesses or witnesses of the expert can be asked to be sworn in or say an appointment.

The arbitrator or the arbitral tribunal may hear the information of a witness or convene a meeting deemed necessary at a particular venue outside the place of the arbitration held. Examination of the witness and expert witness before the arbitrator or the arbitral tribunal, shall be held under the provisions of the Civil Procedural Law. The arbitrator or the arbitral tribunal may conduct a local examination of the disputed goods or anything else relating to the dispute being examined, and in the event deemed necessary, the parties shall be legally called to be able to also attend in the inspection.

According to Adi Sulistiyono, the arbitral institutions include settlement of disputes with approach to the litigation paradigm, as the arbitrator in the Decision still uses a contradiction approach (adversarial) with the result of win lose solution. ${ }^{3}$

Within a period of 30 (thirty) days from the date of the verdict pronounced, the original sheet or an authentic copy of the Arbitral Decision is submitted and registered by the arbitrator or its authority to the Registrar of the District Court. The district Court is a state court whose legal area includes the residence of the respondent, the Arbitral Decision shall be registered to the Registrar of the District court whose legal area includes the residence of the respondent. In this case it means the respondent in the case of an arbitration that has been disconnected. As for the international arbitration decision in Article 65 of Act No. 30 of 1999 has been determined that the recognition and implementation of the international arbitration decision shall be the authority of the District Court of Central Jakarta of course with some conditions that the applicant must fulfill.

Submission and registration is done by recording and signing at the end or on the edge of the ruling by the Registrar of the District Court and the arbitrator or its proxies, and the record is a registration deed. The arbitrator or its proxies shall submit the verdict and the original sheet of appointment as an arbitrator or an authenticity copy to the Registrar of the District Court. No fulfilling provisions of the arbitration decision will be unenforceable. All costs relating to the creation of the registration Act are imposed on the parties.

The arbitral decision is final and has a fixed legal force and binding of the parties. In the event that the parties do not voluntarily execute the arbitral decision, the decision is executed by order of the Chief Court of the Tribunal upon the request of one of the parties to the dispute. The order is given for a period of 30 (thirty) days after the execution request is registered to the Registrar of the District Court. The chairman of the District Court before giving the order of implementation, check in advance whether the arbitral decision meets the provisions of Article 4 and Article 5 of the Arbitration Act, and does not contradict the public order and morality. In the event that an arbitral decision does not meet the provisions, the Chairman of the District Court rejects the application for execution and against the verdict of the state court the Chairman shall not open any legal remedy. The chairman of the District Court does not examine the reason or consideration of the arbitral decision.

The command of the Chief District Court is written on the original sheet and an authentic copy of the Arbitral Decision issued. The arbitral decision, which has been made by the Chairman of the District Court, is executed in accordance with the provisions of the ruling in the civil lawsuit which its verdict have fixed legal force

\section{B. International Arbitration}

The provisions of this place of arbitration are important especially when there is an element of foreign law and the dispute becomes an international civil law dispute. As usual the place of arbitration is carried out can determine the law that should be used to examine the dispute if the parties do not determine for themselves then the arbitrator can determine the place of arbitration. The authorities addressing the issue of recognition and implementation of the Decision of International Abitration is the District Court of Central Jakarta.

The Decision of International Arbitration is only recognized and enforceable in the jurisdiction of the Republic of Indonesia, if it meets the following conditions: 
a. An international arbitration decision is imposed by the arbitrator or an arbitral tribunal in a country with which the Republic of Indonesia is bound to a treaty, both bilateral and multilateral, regarding the recognition and implementation of the Arbitral Decision International

b. An international arbitration decision is limited to a ruling that is according to Indonesian law including the scope of trade law;

c. International arbitration decision can only be implemented in Indonesia limited to decisions not contrary to public order;

d. The Decision of International Arbitration as referred to in letter a concerning the state of the Republic of Indonesia as a party to the dispute, can only be executed after obtaining the right to be executed from the Supreme Court of the Republic of Indonesia hereinafter bestowed on the District Court of Central Jakarta.

The application for implementation of the Decision of international arbitration stipulated in Article 67 shall be conducted after the ruling is submitted and registered by the arbitrator or its authority to the District Court Registrar of Central Jakarta. Submission of application file must be accompanied by:

a. Original sheet or authentic copy of the Decision of International Arbitration, pursuant to the provisions regarding the authentication of foreign documents, and the official translation of the Indonesian language;

b. The original or authentic copy of the Agreement on which the international arbitration decision is based on the provisions concerning the authentication of foreign documents, and the official translation texts in Indonesian language; and

c. Description of the diplomatic representative of the Republic of Indonesia in the country where the The Decision of International Arbitration is set, stating that the applicant country is bound to the agreement, both bilateral and multilateral with the state Indonesia regarding the recognition and implementation of the The Decision of International Arbitration.

Against the ruling of the District Court of Central Jakarta who acknowledges and executes the decisions of international arbitration, it cannot be appealed or cassed. Against the ruling of the District Court of Central Jakarta who refused to acknowledge and implement an international arbitration award, the casation may be filed. The Supreme Court considers and decides on any appeal in the longest period of 90 (ninety) days after the appeal is received by the Supreme Court. The Supreme Court ruling cannot be brought against the resistance attempt. After the chairman of the District Court of Central Jakarta gave an order to execute, then the subsequent implementation was bestowed on the chairman of the district Court which is relatively authorized to execute it. Confiscated execution can be done on the property of wealth as well as the respondent's execution. Procedures for foreclosures and the execution of decisions follow the ordinances as specified in the Civil Procedure Law. (Article 69)
Against the arbitral award the parties may apply for a cancellation if the ruling is alleged to contain the following elements:

a. The letter or documents filed in the examination, after the award is dropped, are recognized false or otherwise false;

b. After the ruling is found a decisive document, which is concealed by the opposing party; or

c. The award is taken from the results of the deception by either party in the examination of the dispute. (Article 70)

Application for annulment of the arbitral award shall be submitted in writing within 30 (thirty) days from the day of submission and registration of the arbitral award to the Registrar of the District Court. Application for cancellation of arbitral awards shall be submitted to the Chairman of the District Court. If the application is granted, the Chairman of the District Court shall further determine the result of full or partial cancellation of the arbitration award. The decision on the cancellation request shall be determined by the Chairman of the District Court within 30 (thirty) days since the application is received. The District court's decision can be filed for appeals to the Supreme Court which breaks down in the first and last level. The Supreme Court considers and decides to appeal for a period of 30 (thirty) days after the appeal is received by the Supreme Court

\section{CONCLUSION}

Arbitration is a way of resolving a civil dispute outside the general judiciary based on an arbitration agreement made in writing by the parties to the dispute. Settlement of disputes through arbitration can be done using national or international arbitral institutions under the agreement of the parties. Arbitrators or arbitral tribunals take decisions based on the provisions of the law, or based on fairness and propriety. The parties may agree on a dispute that occurs or that will occur between them to be resolved by arbitration. Disputes that can be resolved by arbitration are only disputes in the field of trade and concerning rights that according to law and legislation are fully controlled by the parties to the dispute. Disputes that cannot be resolved through arbitration are disputes that according to the laws and regulations cannot be held peace. All examinations of disputes by arbitrators or arbitral tribunals are conducted in private. Settlement of disputes through arbitration can be done using national or international arbitral institutions under the agreement of the parties. Dispute resolution through an arbitral institution is conducted according to the rules and events of the selected institution, unless other than determined by the parties. The arbitrator or arbitral tribunal may order that any document or evidence be accompanied by a translation into the language set by the arbitrator or the arbitral tribunal. Examination of disputes in arbitration shall be conducted in writing. Oral examination may be conducted if approved by the parties or deemed necessary by an arbitrator or arbitral tribunal. The place of arbitration is determined by the arbitrator or the arbitral tribunal, unless self-determined by the parties. This provision of the place of arbitration is especially important when there is an element of foreign law and the dispute becomes an international civil law dispute. The arbitral award 
is final and has the permanent and binding legal force of the parties.

\section{ACKNOWLEDGMENT}

The Decision of Arbitration can only be executed with the ruling of the District Court of Central Jakarta in the form of Implementation order. The dispute settlement agreement or any other opinion in writing shall be final and binding on the parties to be executed in good faith and must be registered in the District Court. The arbitral tribunal may perform fair and faster screening of disputes but the arbitral tribunal has no organ to be able to compel the defeated party to carry out its its verdict, such as a court of executing execution.

\section{REFERENCES}

The template will number citations consecutively within brackets [1]. The sentence punctuation follows the bracket [2]. Refer simply to the reference number, as in [3] - do not use "Ref. [3]" or "reference [3]" except at the beginning of a sentence: "Reference [3] was the first ..."
Number footnotes separately in superscripts. Place the actual footnote at the bottom of the column in which it was cited. Do not put footnotes in the abstract or reference list. Use letters for table footnotes.

Unless there are six authors or more give all authors' names; do not use "et al.". Papers that have not been published, even if they have been submitted for publication, should be cited as "unpublished" [4]. Papers that have been accepted for publication should be cited as "in press" [5]. Capitalize only the first word in a paper title, except for proper nouns and element symbols.

For papers published in translation journals, please give the English citation first, followed by the original foreignlanguage citation [6].

[1] Undang - Undang Republik Indonesia Nomor 30 Tahun 1999 Tentang Arbitrase Dan Alternatif Penyelesaian Sengketa, (1999).

[2] Marzuki, P. M. (2011). Ilmu Hukum Dan Penelitian Hukum.

[3] Situmorang, M. (2017). Pelaksanaan Putusan Arbitrase Nasional Di Indonesia (Enforcement of National Arbitration Award in Indonesia). Jurnal Penelitian Hukum DE JURE, 17(740).

[4] Sulistiyono, A. (2007). Mengembangkan Paradigma Non Litigasi di Indonesia. UNS Press. 